\title{
Synthesis, crystal structure, and thermal stability of double borate $\mathrm{Na}_{3} \mathrm{ErB}_{2} \mathrm{O}_{6}$
}

\author{
Alexey K. Subanakov *(D), Evgeniy V. Kovtunets (D), Bair G. Bazarov, \\ Jibzema G. Bazarova
}

Baikal Institute of Nature Management SB RAS, 670047 Sakhyanovoy st., 6, Ulan-Ude, Russia

* Corresponding author: subanakov@binm.bscnet.ru

This article belongs to the regular issue.

(c) 2021, The Authors. This article is published in open access form under the terms and conditions of the Creative Commons Attribution (CC BY) license (http://creativecommons.org/licenses/by/4.o/).

\section{Abstract}

Double borate $\mathrm{Na}_{3} \mathrm{ErB}_{2} \mathrm{O}_{6}$ was synthesized by the solid-state reaction. The crystal structure of $\mathrm{Na}_{3} \mathrm{ErB}_{2} \mathrm{O}_{6}$ was refined by the Rietveld method: $P 2_{1} / c, a=6.49775(14) \AA, \quad b=8.50424(17) \AA, \quad c=12.0067(3) \AA$, $\beta=118.4797(9)^{\circ}, Z=4$. The crystal structure of $\mathrm{Na}_{3} \mathrm{ErB}_{2} \mathrm{O}_{6}$ consists of $-\left[\mathrm{ErO}_{6}\right]_{\infty}$-chains along the " $b$ " axis, which are linked by $\mathrm{BO}_{3}$ triangles in a three-dimensional framework. Sodium atoms occupy empty positions inside the channels. The thermal behavior of $\mathrm{Na}_{3} \mathrm{ErB}_{2} \mathrm{O}_{6}$ was studied in detail in the range of $25^{-1150}{ }^{\circ} \mathrm{C}$ range by $\mathrm{DSC}$ and TG methods. $\mathrm{Na}_{3} \mathrm{ErB}_{2} \mathrm{O}_{6}$ congruently melts at $1116{ }^{\circ} \mathrm{C}$. Based on the results of DSC measurements, three reversible phase transitions were found for $\mathrm{Na}_{3} \mathrm{ErB}_{2} \mathrm{O}_{6}$.
\end{abstract}

\section{Keywords}

sodium rare-earth borate

solid-state reaction

crystal structure

Rietveld refinement

thermal analysis

Received: 05.10.2021

Revised: 18.10.2021

Accepted: 18.10.2021

Available online: 20.10.2021

\section{Introduction}

Borates are considered to be attractive functional materials for non-linear optic and luminescence due to their wide variety of crystal structures, low synthesis temperature, and environmental benignity [1-13]. Today commercially used nonlinear optical crystals of borates with superior optical properties are $\beta-\mathrm{BaB}_{2} \mathrm{O}_{4}$ [14] and $\mathrm{LiB}_{3} \mathrm{O}_{5}$ [15]. Recent studies of borates are related to birefringent materials [16] and self-frequency-doubling (SFD) laser ones [17]. SFD crystals belong to multi-functional materials and possess both laser and frequency doubling properties. The basic requirements for an efficient SFD laser crystal are excellent laser properties and excellent nonlinear optical properties with suitable birefringence. Therefore, SFD materials contained rare-earth elements and a nonlinear framework.

To search new SFD materials, the oxide systems based on alkaline, rare earth, and boron were extensively studied. Exploration of the $\mathrm{Na}_{2} \mathrm{O}-\mathrm{R}_{2} \mathrm{O}-\mathrm{B}_{2} \mathrm{O}_{3}$ systems revealed the existence of a number of double borates: $\mathrm{Na}_{2} \mathrm{R}_{2}\left(\mathrm{BO}_{3}\right)_{2}$ [18-20], $\mathrm{Na}_{3} \mathrm{RB}_{2} \mathrm{O}_{6}$ [21-23], $\mathrm{Na}_{3} \mathrm{R}_{2} \mathrm{~B}_{3} \mathrm{O}_{9} \quad$ [21,24-26], $\mathrm{Na}_{3} \mathrm{Y}_{3} \mathrm{~B}_{4} \mathrm{O}_{12}$ [27], $\mathrm{Na}_{3} \mathrm{R}_{9} \mathrm{O}_{3} \mathrm{~B}_{8} \mathrm{O}_{24}[28,29]$. Our attention was attracted by double borates with the general formula $\mathrm{Na}_{3} \mathrm{RB}_{2} \mathrm{O}_{6}$. This family of compounds includes borates with large lanthanides such as $\mathrm{Na}_{3} \mathrm{LaB}_{2} \mathrm{O}_{6}$ [21], $\mathrm{Na}_{3} \mathrm{PrB}_{2} \mathrm{O}_{6}$ [22], $\mathrm{Na}_{3} \mathrm{SmB}_{2} \mathrm{O}_{6}$ [22], $\mathrm{Na}_{3} \mathrm{EuB}_{2} \mathrm{O}_{6}$ [22], $\mathrm{Na}_{3} \mathrm{YB}_{2} \mathrm{O}_{6}$ [23] and $\mathrm{Na}_{3} \mathrm{GdB}_{2} \mathrm{O}_{6}$ [23]. The subject of our study is the possibility of replacing large lanthanides with erbium. The crystal structure and thermal stability of double borate $\mathrm{Na}_{3} \mathrm{ErB}_{2} \mathrm{O}_{9}$ was studied in the present work.

\section{Experimental}

The title compounds were prepared by solid state reactions using high purity starting reagents: $\mathrm{Na}_{2} \mathrm{CO}_{3}$ (99.8\%, Sigma Aldrich Ltd.), $\mathrm{Er}_{2} \mathrm{O}_{3}$ (99.9\%, Red Chemist, Ltd., Russia), and $\mathrm{H}_{3} \mathrm{BO}_{3}$ (99.5\%, Sigma Aldrich Ltd.). Before weighing, $\mathrm{Er}_{2} \mathrm{O}_{3}$ had been preheated at $850{ }^{\circ} \mathrm{C}$ for 8 hours to remove absorbed water. The reagents were weighed on an analytical balance with an accuracy of $0.5 \mathrm{mg}$. The mixtures of $\mathrm{Na}_{2} \mathrm{CO}_{3}, \mathrm{Er}_{2} \mathrm{O}_{3}$, and $\mathrm{H}_{3} \mathrm{BO}_{3}$ at molar ratio 3:1:2 were thoroughly ground in an agate mortar, slowly heated up to $300{ }^{\circ} \mathrm{C}$, and were kept for 5 hours. Then the samples were reground and annealed at $600{ }^{\circ} \mathrm{C}$ for 5 hours and finally at $700{ }^{\circ} \mathrm{C}$ for 40 hours with intermediate grindings until equilibrium was reached. Temperature was measured with a Pt-PtRh thermocouple. The temperatures up to $1200{ }^{\circ} \mathrm{C}$ were controlled with an accuracy of $\pm 2{ }^{\circ} \mathrm{C}$ with an OMRON instrument. The equilibrium was considered to be reached only when two successive heat treatments resulted in identical X-ray diffraction patterns.

Powder X-ray diffraction data were recorded by a D8 ADVANCE Bruker AXS diffractometer (Vantec-1 detector) at room temperature using $\mathrm{Cu} \mathrm{K} \alpha$ radiation and scanning 
from $2 \theta=8^{\circ}$ to $100^{\circ}$ in increments of $0.02^{\circ}$ and a counting time of $0.1 \mathrm{~s} /$ step. Phase purity was verified by powder X-ray diffraction (XRD) and the profile was compared to that reported for the isostructural phase $\mathrm{Na}_{3} \mathrm{NdB}_{2} \mathrm{O}_{6}$.

The TOPAS 4.2 [30] software suite was used to analyze the experimental data and to perform the Rietveld refinement of the obtained compound. All peaks in the X-ray powder diffraction pattern for $\mathrm{Na}_{3} \mathrm{ErB}_{2} \mathrm{O}_{9}$ were indexed satisfactory in a monoclinic cell (space group $P_{2} / c$ ).

Differential scanning calorimetry (DSC) and thermogravimetric (TG) measurements were performed on an STA 449 F1 Jupiter thermoanalyzer (NETZSCH) in the temperature range of $30-1150{ }^{\circ} \mathrm{C}$ in argon flow. Pt crucibles were used as vessels. Pt-PtRh thermocouples were used for temperature measurement. The precision of temperature measurement was $\pm 1{ }^{\circ} \mathrm{C}$. The heating and cooling rates were $10^{\circ} \mathrm{C} / \mathrm{min}$.

\section{Results and discussion}

The synthesized sample of $\mathrm{Na}_{3} \mathrm{ErB}_{2} \mathrm{O}_{6}$ is pink powder, which is characteristic for the Er-containing oxides. The structure of $\mathrm{Na}_{3} \mathrm{NdB}_{2} \mathrm{O}_{6}$ was used as initial model for the Rietveld refinement to define the positions of atoms. They were refined by isotropic approximation with "soft" limitations of the B-O distance and the B-O-B bond angles. The refined parameters were added sequentially with the graphical simulation of the background in continuous. The Pearson VII function was used to describe the shape of peaks. The isotropic displacement parameters $\left(B_{\text {iso }}\right)$ for the $\mathrm{Er}$ and $\mathrm{Na}$ atoms were refined separately, while for the $\mathrm{O}$ and B atoms they were taken as equivalent. The refinement process included corrections for the sample preferred orientation and anisotropic broadening of peaks within the model of spherical harmonics.

The refinement was stable and gave low $R$-factors (Fig. 1, Table 1). $\mathrm{Na}_{3} \mathrm{ErB}_{2} \mathrm{O}_{6}$ was crystallized in the monoclinic system with the space group $P_{2} / c$. The unit cell parameters are: $a=6.49775(14) \AA, \quad b=8.50424(17) \AA, \quad c=12.0067(3) \AA$, $\beta=118.4797(9)^{\circ}, Z=4$. Coordinates of atoms are given in Table 2. Further details of the crystal structure may be obtained from supplementary material.

In the structure of $\mathrm{Na}_{3} \mathrm{ErB}_{2} \mathrm{O}_{6}$ (Fig. 2a), Er atoms are coordinated by seven $\mathrm{O}$ atoms in a distorted pentagonal bipyramid. The bipyramids share corners, forming a zigzag chain along the " $b$ " direction, and the chain is reinforced by the $\mathrm{B}_{1} \mathrm{O}_{3}$ group, which uses all its three $\mathrm{B}-\mathrm{O}$ bonds to join the neighboring bipyramids (Fig. 2a). Along with the " $a$ " and " $c$ " directions, these chains are connected via the $\mathrm{B} 2 \mathrm{O}_{3}$ groups, thereby constructing a threedimensional framework. Na1 and Na3 atoms are located in the interlayer channels and Na2 atom sits in the inlayer empty positions (Fig. $2 \mathrm{~b}-\mathrm{d}$ ). Three $\mathrm{Na}$ atoms are coordinated by seven, six, and four $\mathrm{O}$ atoms, respectively.

The main bond lengths $(\AA)$ and angles $\left({ }^{\circ}\right)$ of $\mathrm{Na}_{3} \mathrm{ErB}_{2} \mathrm{O}_{6}$ are shown in Table 3.

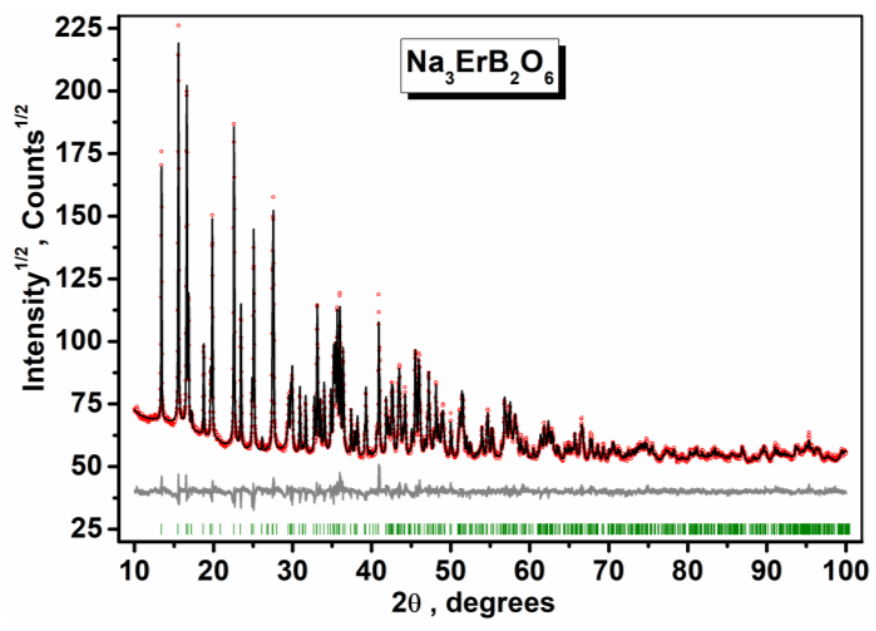

Fig. 1 XRD data for $\mathrm{Na}_{3} \mathrm{ErB}_{2} \mathrm{O}_{6}$ refined by the Rietveld analysis: measured (red points), calculated (black profile) and difference between experimental points and calculated profile (grey curve)

Table 1 Crystallographic data for $\mathrm{Na}_{3} \mathrm{ErB}_{2} \mathrm{O}_{6}$ phase at room temperature

\begin{tabular}{|c|c|}
\hline Chemical formula & $\mathrm{Na}_{3} \mathrm{ErB}_{2} \mathrm{O}_{6}$ \\
\hline Space group & $P 2_{1} / c(14)$ \\
\hline Formula weight, g/mol & 353.9 \\
\hline $\begin{array}{l}\text { Unit cell dimensions, } \AA \\
\alpha=\gamma=90^{\circ}\end{array}$ & $\begin{array}{c}a=6.49775(14) \\
b=8.50424(17) \\
c=12.0067(3) \\
\beta=118.4797(9)^{\circ}\end{array}$ \\
\hline Cell volume, $\AA^{3}$ & $583.18(2)$ \\
\hline$Z$ & 4 \\
\hline Calculated density $\left(\mathrm{g} / \mathrm{cm}^{3}\right)$ & 4.163 \\
\hline$R_{p}, \%$ & 2.571 \\
\hline$R_{w p}, \%$ & 3.534 \\
\hline$R_{\text {exp }}, \%$ & 1.572 \\
\hline Bragg $R$-factor, $\%$ & 1.864 \\
\hline$\chi_{2}$ & 2.249 \\
\hline
\end{tabular}

Table 2 Fractional atomic coordinates and isotropic or equivalent isotropic displacement parameters of $\mathrm{Na}_{3} \mathrm{ErB}_{2} \mathrm{O}_{6}$ structure

\begin{tabular}{lcccc}
\hline & $X$ & $y$ & $z$ & $B_{\text {iso }}{ }^{*} B_{\text {eq }}$ \\
\hline $\mathrm{Er}$ & $0.0970(3)$ & $0.1261(1)$ & $0.3287(1)$ & $0.9(2)$ \\
\hline $\mathrm{Na} 1$ & $0.380(2)$ & $0.8039(8)$ & $0.3841(7)$ & $1.1(3)$ \\
\hline $\mathrm{Na} 2$ & $0.058(2)$ & $0.2963(8)$ & $0.0802(8)$ & $0.9(3)$ \\
\hline $\mathrm{Na} 3$ & $0.331(2)$ & $0.9488(8)$ & $0.1134(7)$ & $3.1(3)$ \\
\hline $\mathrm{B} 1$ & $0.139(3)$ & $0.4379(7)$ & $0.3695(8)$ & $1.0(6)$ \\
\hline $\mathrm{B} 2$ & $0.351(1)$ & $0.5864(8)$ & $0.1209(5)$ & $1.0(6)$ \\
\hline $\mathrm{O} 1$ & $0.255(2)$ & $0.334(1)$ & $0.4714(9)$ & $0.5(2)$ \\
\hline $\mathrm{O} 2$ & $0.049(2)$ & $0.373(2)$ & $0.2513(7)$ & $0.5(2)$ \\
\hline $\mathrm{O} 3$ & $0.137(2)$ & $0.600(1)$ & $0.3911(9)$ & $0.5(2)$ \\
\hline $\mathrm{O} 4$ & $0.226(1)$ & $0.674(1)$ & $0.1611(5)$ & $0.5(2)$ \\
\hline $\mathrm{O} 5$ & $0.251(2)$ & $0.505(1)$ & $0.0086(7)$ & $0.5(2)$ \\
\hline & $0.413(1)$ & $0.080(1)$ & $0.3075(5)$ & $0.5(2)$ \\
\hline
\end{tabular}



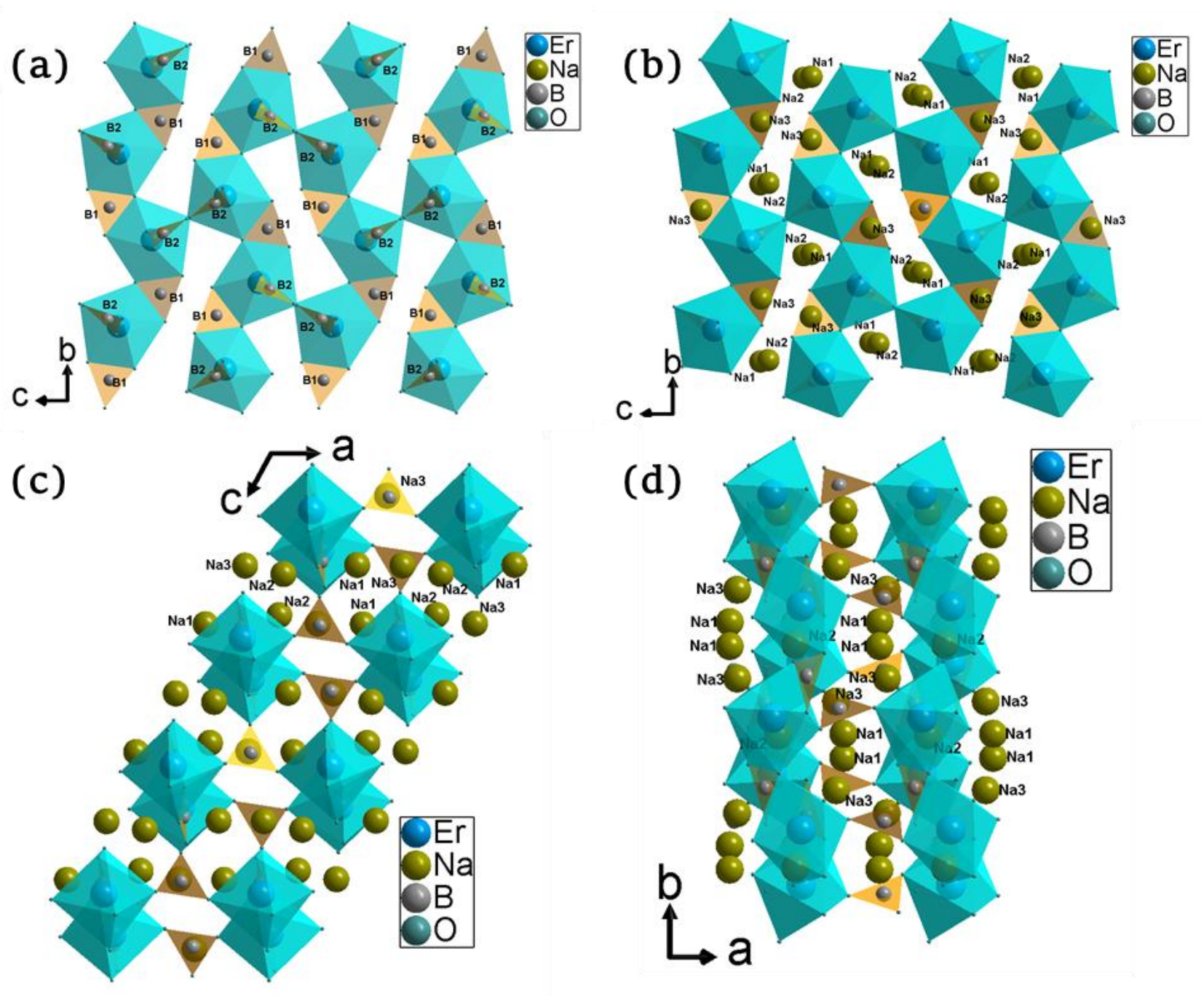

Fig. 2 The crystal structure of $\left.\mathrm{Na}_{3} \mathrm{RB}_{2} \mathrm{O}_{9}: \mathrm{a}, \mathrm{b}\right) \mathrm{ErO}_{7}$ chains, $\mathrm{BO}_{3}$ triangles (a) and $\mathrm{Na}$ atoms (b) along $a$ axis; b, c) a general view along $b$ and $c$ axes

The DSC curves recorded for $\mathrm{Na}_{3} \mathrm{ErB}_{2} \mathrm{O}_{6}$ are shown in Fig. 3. Four endothermic signals at $717,907,1014$, and $1116{ }^{\circ} \mathrm{C}$ were detected during the sample's first heating, as shown in Fig. 3. The endothermic peak at $1116{ }^{\circ} \mathrm{C}$ corresponds to the melting point of $\mathrm{Na}_{3} \mathrm{ErB}_{2} \mathrm{O}_{6}$. The X-ray diffraction measurements indicate the congruent melting of the borate (Fig. 4). To determine the nature of the endothermal effects at $717,907,1014^{\circ} \mathrm{C}$ and prove congruent melting, the same sample was recorded in the "heating-cooling" mode over the temperature range of $100-1150{ }^{\circ} \mathrm{C}$ (with melting). At first cooling, $\mathrm{Na}_{3} \mathrm{ErB}_{2} \mathrm{O}_{6}$ shows exothermic effects at $712,831,1000,1098^{\circ} \mathrm{C}$. The second cooling reveals a new exothermic effect at $706{ }^{\circ} \mathrm{C}$ that seems to correspond to $\mathrm{Na}_{3} \mathrm{ErB}_{2} \mathrm{O}_{6}$ partial decomposition, which is confirmed by X-ray analysis. The observed temperatures hystereses are about 5, 76, 14, 18 degrees. Thus, the signature observed at $600-1150{ }^{\circ} \mathrm{C}$ reveals the existence of reversible phase transitions (type I) in $\mathrm{Na}_{3} \mathrm{ErB}_{2} \mathrm{O}_{6}$ and, respectively, additional experiments are needed to define the structure of the hightemperature modification of $\beta, \gamma-\mathrm{Na}_{3} \mathrm{ErB}_{2} \mathrm{O}$.
Table 3 Main bond lengths $(\AA)$ and angles $\left({ }^{\circ}\right)$ of $\mathrm{Na}_{3} \mathrm{ErB}_{2} \mathrm{O}_{6}$

\begin{tabular}{cccc}
\hline $\mathrm{Er}-\mathrm{O} 1$ & $2.33(1)$ & $\mathrm{Na} 2-\mathrm{O} 5$ & $2.55(1)$ \\
\hline $\mathrm{Er}-\mathrm{O} 2^{\mathrm{i}}$ & $2.36(1)$ & $\mathrm{Na} 2-\mathrm{O} 6$ & $3.19(1)$ \\
\hline $\mathrm{Er}-\mathrm{O} 2$ & $2.26(2)$ & $\mathrm{Na} 3-\mathrm{O} 1^{\mathrm{x}}$ & $2.4 \mathrm{O}(1)$ \\
\hline $\mathrm{Er}-\mathrm{O} 3^{\mathrm{i}}$ & $2.32(1)$ & $\mathrm{Na} 3-\mathrm{O} 3^{\mathrm{x}}$ & $2.38(1)$ \\
\hline $\mathrm{Er}-\mathrm{O} 4^{\mathrm{i}}$ & $2.2 \mathrm{O}(1)$ & $\mathrm{Na} 3-\mathrm{O} 4$ & $2.57(1)$ \\
\hline $\mathrm{Er}-\mathrm{O} 5^{\mathrm{ii}}$ & $2.2 \mathrm{O}(1)$ & $\mathrm{Na} 3-\mathrm{O} 6^{\mathrm{vii}}$ & $2.4 \mathrm{O}(1)$ \\
\hline $\mathrm{Er}-\mathrm{O} 6$ & $2.22(1)$ & $\mathrm{B} 1-\mathrm{O} 1$ & $1.4 \mathrm{O}(1)$ \\
\hline $\mathrm{Na} 1-\mathrm{O} 1^{\mathrm{iii}}$ & $2.5 \mathrm{O}(1)$ & $\mathrm{B} 1-\mathrm{O} 2$ & $1.37(1)$ \\
\hline $\mathrm{Na} 1-\mathrm{O} 2^{\mathrm{iv}}$ & $2.53(1)$ & $\mathrm{B} 1-\mathrm{O} 3$ & $1.4 \mathrm{O}(1)$ \\
\hline $\mathrm{Na} 1-\mathrm{O} 3$ & $2.38(1)$ & $\mathrm{B} 2-\mathrm{O} 4$ & $1.35(1)$ \\
\hline $\mathrm{Na} 1-\mathrm{O} 4$ & $2.61(1)$ & $\mathrm{B} 2-\mathrm{O} 5$ & $1.37(1)$ \\
\hline $\mathrm{Na} 1-\mathrm{O} 5^{\mathrm{v}}$ & $2.72(1)$ & $\mathrm{B} 2-\mathrm{O} 6^{\mathrm{v}}$ & $1.36(1)$ \\
\hline $\mathrm{Na} 1-\mathrm{O} 5^{\mathrm{vi}}$ & $2.6 \mathrm{O}(1)$ & $\mathrm{O} 1-\mathrm{B} 1-\mathrm{O} 2$ & $116(1)$ \\
\hline $\mathrm{Na} 1-\mathrm{O} 6^{\mathrm{vii}}$ & $2.56(1)$ & $\mathrm{O} 1-\mathrm{B} 1-\mathrm{O} 3$ & $12 \mathrm{O}(1)$ \\
\hline $\mathrm{Na} 2-\mathrm{O} 1^{\mathrm{viii}}$ & $2.48(1)$ & $\mathrm{O} 2-\mathrm{B} 1-\mathrm{O} 3$ & $123(1)$ \\
\hline $\mathrm{Na}-\mathrm{O} 2$ & $2.18(1)$ & $\mathrm{O} 4-\mathrm{B} 2-\mathrm{O} 5$ & $123(7)$ \\
\hline $\mathrm{Na} 2-\mathrm{O} 3^{\mathrm{i}}$ & $2.22(1)$ & $\mathrm{O} 4-\mathrm{B} 2-\mathrm{O} 6^{\mathrm{v}}$ & $12 \mathrm{O}(5)$ \\
\hline $\mathrm{Na} 2-\mathrm{O} 4^{\mathrm{ix}}$ & $2.6 \mathrm{O}(1)$ & $\mathrm{O} 5-\mathrm{B} 2-\mathrm{O} 6^{\mathrm{v}}$ & $118(1)$ \\
\hline $\mathrm{Na} 2-\mathrm{O} 5^{\mathrm{ix}}$ & $2.44(1)$ & & \\
\hline $\mathrm{Sy}^{\mathrm{n} m}$ & & \\
\hline
\end{tabular}

Symmetry codes: (i) $-x, y-1 / 2,-z+1 / 2$; (ii) $x,-y+1 / 2, z+1 / 2$;

(iii) $-x+1,-y+1,-z+1$; (iv) $-x, y+1 / 2,-z+1 / 2$; (v) $-x+1, y+1 / 2$,

$-z+1 / 2$; (vi) $x,-y+3 / 2, z+1 / 2$; (vii) $x, y+1, z$; (viii) $x,-y+1 / 2$, $z-1 / 2$; (ix) $-x,-y+1,-z$; (x) $x,-y+3 / 2, z-1 / 2$. 
It should be pointed out that the transition was not found in $\mathrm{Na}_{3} \mathrm{RB}_{2} \mathrm{O}_{6}(\mathrm{R}=\mathrm{Pr}, \mathrm{Sm}, \mathrm{Eu})$ [22]. Respectively, it can be reasonably assumed that the appearance of the phase transitions is observed only for the $\mathrm{Na}_{3} \mathrm{RB}_{2} \mathrm{O}_{6}$ borates where rare earth elements have small ionic radius.

An X-ray examination of solid-state interactions between the components of the $\mathrm{Na}_{2} \mathrm{O}-\mathrm{Er}_{2} \mathrm{O}_{3}-\mathrm{B}_{2} \mathrm{O}_{3}$ system resulted in finding double borate $\mathrm{Na}_{3} \mathrm{ErB}_{2} \mathrm{O}_{6} . \mathrm{Na}_{3} \mathrm{ErB}_{2} \mathrm{O}_{6}$ was synthesized by solid-state reaction. The crystal structure of $\mathrm{Na}_{3} \mathrm{ErB}_{2} \mathrm{O}_{6}$ was refined by the Rietveld analysis. $\mathrm{Na}_{3} \mathrm{ErB}_{2} \mathrm{O}_{6}$ consists of $\mathrm{ErO}_{7}$ distorted pentagonal bipyramids and $\mathrm{BO}_{3}$ groups. $\mathrm{Na}_{3} \mathrm{ErB}_{2} \mathrm{O}_{6}$ congruently melts at $1116^{\circ} \mathrm{C}$. The DSC and TG experiments assume that after melting $\mathrm{Na}_{3} \mathrm{ErB}_{2} \mathrm{O}_{6}$ decomposing with formation of $\mathrm{Er}_{2} \mathrm{O}_{3}$. The observed endothermic effects on the DSC curve are assumed to be attributed to high-temperature phase transitions of the title compound. This assumption prompts us to thoroughly investigate this family of compounds in the future.

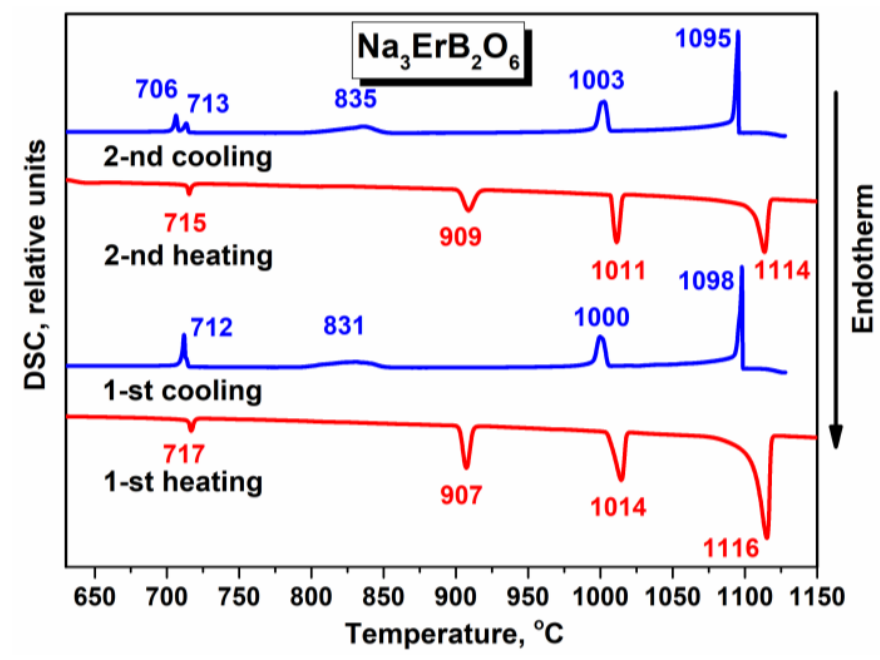

Fig. 3 DSC measurement results

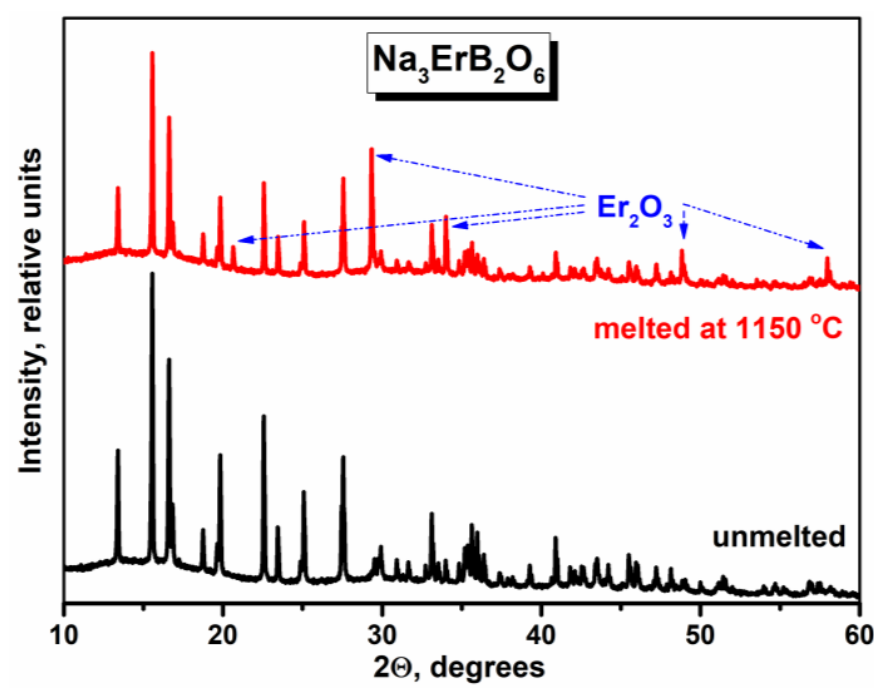

Fig. 4 X-ray patterns of unmelted and melted $\mathrm{Na}_{3} \mathrm{ErB}_{2} \mathrm{O}_{6}$ specimen

\section{Conclusions}

An X-ray examination of solid-state interactions between the components of the $\mathrm{Na}_{2} \mathrm{O}-\mathrm{Er}_{2} \mathrm{O}_{3}-\mathrm{B}_{2} \mathrm{O}_{3}$ system resulted in finding the double borate, $\mathrm{Na}_{3} \mathrm{ErB}_{2} \mathrm{O}_{6} \cdot \mathrm{Na}_{3} \mathrm{ErB}_{2} \mathrm{O}_{6}$ was synthesized by solid-state reactions. The crystal structure of $\mathrm{Na}_{3} \mathrm{ErB}_{2} \mathrm{O}_{6}$ was refined by the Rietveld analysis. $\mathrm{Na}_{3} \mathrm{ErB}_{2} \mathrm{O}_{6}$ consists of $\mathrm{ErO}_{7}$ distorted pentagonal bipyramids and $\mathrm{BO}_{3}$ groups. $\mathrm{Na}_{3} \mathrm{ErB}_{2} \mathrm{O}_{6}$ congruently melts at $1116{ }^{\circ} \mathrm{C}$. The DSC and TG experiments demonstrated that after melting $\mathrm{Na}_{3} \mathrm{ErB}_{2} \mathrm{O}_{6}$ decomposes with formation of $\mathrm{Er}_{2} \mathrm{O}_{3}$. The observed endothermic effects on the DSC curve are assumed to be attributed to high-temperature phase transitions of the title compound. This assumption prompts us to thoroughly investigate this family of compounds in the future.

\section{Acknowledgments}

The work was supported by Basic Project of BINM SB RAS № 0273-2021-0008. X-ray powder diffraction and thermal analysis were obtained using the equipment of the Collective Use Center BINM SB RAS.

\section{References}

1. Mutailipu M, Poeppelmeier KR, Pan S. Borates: A Rich Source for Optical Materials. Chem Rev. 2021;121:1130-1202. doi:10.1021/acs.chemrev.0c00796

2. Yang SH, Xue H, Guo SP. Borates as promising electrode materials for rechargeable batteries. Coord Chem Rev. 2021;427. doi:10.1016/j.ccr.2020.213551

3. Leonyuk NI, Maltsev VV, Volkova EA. Crystal chemistry of high-temperature borates. Molecules. 2020;25. doi:10.3390/MOLECULES25102450

4. Topnikova AP, Belokoneva EL. The structure and classification of complex borates. Russ Chem Rev. 2019;88:204-228. doi: $10.1070 / \operatorname{rcr} 4835$

5. Mutailipu M, Zhang M, Yang Z, Pan S. Targeting the Next Generation of Deep-Ultraviolet Nonlinear Optical Materials: Expanding from Borates to Borate Fluorides to Fluorooxoborates. Acc Chem Res. 2019;52:791-801. doi:10.1021/acs.accounts.8bo0649

6. Becker P. Borate materials in nonlinear optics. Adv Mater. 1998;10:979-992. doi:10.1002/(SICI)15214095(199809)10:13<979::AID-ADMA979>3.0.CO;2-N

7. Chen C, Wu Y, Li R. The development of new NLO crystals in the borate series. J Cryst Growth. 1990;99:790-798. doi:10.1016/So022-0248(08)80028-0

8. Kovtunets EV, Subanakov AK, Bazarov BG. Synthesis, structure and luminescent properties of the new double borate $\mathrm{K}_{3} \mathrm{Eu}_{3} \mathrm{~B}_{4} \mathrm{O}_{12}$. Kondens Sredy Mezhfaznye Granitsy. 2020;22:219-224. doi:10.17308/kcmf.2020.22/2823

9. Subanakov AK, Kovtunets EV, Bazarov BG, Dorzhieva SG, Bazarova JG. New double holmium borates: $\mathrm{Rb}_{3} \mathrm{HoB}_{6} \mathrm{O}_{12}$ and $\mathrm{Rb}_{3} \mathrm{Ho}_{2} \mathrm{~B}_{3} \mathrm{O}_{9}$. Solid State Sci. 2020;105. doi:10.1016/j.solidstatesciences.2020.106231

10. Subanakov AK, Kovtunets EV, Bazarov BG, Pugachev AM, Sofich DO, Bazarova JG. Exploration of structural, thermal and vibrational properties of new noncentrosymmetric double borate $\mathrm{Rb}_{3} \mathrm{Tm}_{2} \mathrm{~B}_{3} \mathrm{O}_{9}$. Solid State Sci. 2021;120. doi:10.1016/j.solidstatesciences.2021.106719

11. Xia M, Shen S, Lu J, Sun Y, Li R. K3Li3Gd7(BO3)9: A New Gadolinium-Rich Orthoborate for Cryogenic Magnetic Cooling. 
Chem - A Eur J. 2018;24:3147-3150.

doi:10.1002/chem.201705669

12. Xia M, Zhai K, Lu J, Sun Y, Li RK. Orthoborates $\operatorname{LiCdRE}_{5}\left(\mathrm{BO}_{3}\right)_{6}$ $(\mathrm{RE}=\mathrm{Sm}-\mathrm{Lu}$ and $\mathrm{Y})$ with Rare-Earth Ions on a Triangular Lattice: Synthesis, Crystal Structure, and Optical and Magnetic Properties. Inorg Chem. 2017;56:8100-8105. doi:10.1021/acs.inorgchem.7boo756

13. Xia M-J, Li RK. A new quaternary rare earth borate, $\mathrm{CsLi}_{2} \mathrm{Gd}_{4}\left(\mathrm{BO}_{3}\right)_{5}$. Acta Crystallogr Sect E Struct Reports Online. 2007;63. doi:10.1107/S1600536807036586

14. Chen $\mathrm{C}, \mathrm{Wu} \mathrm{Y,} \mathrm{Li} \mathrm{R.} \mathrm{The} \mathrm{development} \mathrm{of} \mathrm{new} \mathrm{NLO} \mathrm{crystals} \mathrm{in}$ the borate series. J Cryst Growth. 1990;99:790-798. doi:10.1016/S0022-0248(08)80028-0

15. Chen C, Li R. The anionic group theory of the non-linear optical effect and its applications in the development of new highquality NLO crystals in the borate series. Int Rev Phys Chem. 1988;8:65-91. doi:10.1080/01442358909353223

16. Qin F, Li RK. Predicting refractive indices of the borate optical crystals. J Cryst Growth. 2011;318:642-644. doi:10.1016/J.JCRYSGRO.2010.08.037

17. Yu H, Pan Z, Zhang H, Wang J. Recent advances in selffrequency-doubling crystals. J Mater. 2016;2:55-65. doi:10.1016/j.jmat.2015.12.001

18. Jia Z, Xia M. Congruent melt terbium-rich borate $\mathrm{Na}_{2} \mathrm{~Tb}_{2} \mathrm{~B}_{2} \mathrm{O}_{7}$ : Synthesis, crystal structure, optical and magnetic properties. J Alloys Compd. 2018;743:537-542. doi:10.1016/j.jallcom.2018.02.031

19. Shan F, Zhang G, Yao J, Xu T, Zhang X, Fu Y, et al. Growth, structure, and optical properties of a self-activated crystal: $\mathrm{Na}_{2} \mathrm{Nd}_{2} \mathrm{O}\left(\mathrm{BO}_{3}\right)_{2}$. Opt Mater (Amst). 2015;46:461-466. doi:10.1016/j.optmat.2015.05.004

20. Nagpure PA, Omanwar SK. Synthesis and photoluminescence study of rare earth activated phosphor $\mathrm{Na}_{2} \mathrm{La}_{2} \mathrm{~B}_{2} \mathrm{O}_{7}$. J Lumin. 2012;132:2088-2091. doi:10.1016/j.jlumin.2012.03.068
21. Mascetti J, Fouassier C, Hagenmuller P. Concentration quenching of the $\mathrm{Nd}^{3+}$ emission in alkali rare earth borates. J Solid State Chem. 1983;50:204-212. doi:10.1016/0022-4596(83)90189-5

22. Wang Z, Li H, Cai G, Jin Z. Synthesis, crystal structure, and thermal stability of new borates $\mathrm{Na}_{3} \mathrm{REB}_{2} \mathrm{O}_{6}(\mathrm{RE}=\mathrm{Pr}, \mathrm{Sm}, \mathrm{Eu})$. Powder Diffr. 2016;31:110-117. doi:10.1017/So885715616000051

23. Zhang $\mathrm{Y}$, Chen $\mathrm{XL}$, Liang JK, Xu T. Synthesis and structural study of new rare earth sodium borates $\mathrm{Na}_{3} \mathrm{Ln}\left(\mathrm{BO}_{3}\right)_{2}$ (Ln=Y, Gd). J Alloys Compd. 2002;333:72-75. doi:10.1016/Sog25-8388(01)01689-9

24. Zhang G, Wu Y, Fu P, Wang G, Liu H, Fan G, et al. A new sodium samarium borate $\mathrm{Na}_{3} \mathrm{Sm}_{2}\left(\mathrm{BO}_{3}\right)_{3}$. J Phys Chem Solids. 2001;63:145-9. doi:10.1016/S0022-3697(01)00090-7

25. Yang Z, Ning Y, Keszler DA. $\mathrm{Na}_{3} \mathrm{Sc}_{2}\left(\mathrm{BO}_{3}\right)_{3}$. Acta Crystallogr Sect E Struct Reports Online. 2006;62:266-268. doi:10.1107/S1600536806036737

26. Zhou WW, Zhuang RZ, Zhao W, Wang GF, Zhang LZ, Ma JG, et al. Second harmonic generation in $\mathrm{Na}_{3} \mathrm{Gd}_{2}\left(\mathrm{BO}_{3}\right)_{3}$ crystals. Cryst Res Technol. 2011;46:926-930. doi:10.1002/crat.201100077

27. Shan F, Kang L, Zhang G, Yao J, Lin Z, Xia M, et al. $\mathrm{Na}_{3} \mathrm{Y}_{3}\left(\mathrm{BO}_{3}\right)_{4}$ : A new noncentrosymmetric borate with an openframework structure. Dalt Trans. 2016;45:7205-7208. doi:10.1039/c6dtoog5of

28. Gravereau P, Chaminade JP, Pechev S, Nikolov V, Ivanova D, Peshev P. $\mathrm{Na}_{3} \mathrm{La}_{9} \mathrm{O}_{3}\left(\mathrm{BO}_{3}\right)_{8}$, a new oxyborate in the ternary system $\mathrm{Na}_{2} \mathrm{O}-\mathrm{La}_{2} \mathrm{O}_{3}-\mathrm{B}_{2} \mathrm{O}_{3}$ : Preparation and crystal structure. Solid State Sci. 2002. doi:10.1016/S1293-2558(02)01344-4

29. Zhang J, Zhang G, Li Y, Wu Y, Fu P, Wu Y. Thermophysical properties of a new nonlinear optical $\mathrm{Na}_{3} \mathrm{La}_{9} \mathrm{O}_{3}\left(\mathrm{BO}_{3}\right)_{8}$ crystal. Cryst Growth Des. 2010;10:4965-4967. doi: $10.1021 / \operatorname{cg} 1010743$

30. Coelho AA. Topas: General Profile and Structure Analysis Software for Powder Diffraction Data. Bruker AXS, 2005. 